\title{
THE TRAVEL ADVICE AS AN INHIBITING FACTOR OF TOURIST MOVEMENT
}

\author{
Dimitrios Mylonopoulos, Technological Education Institute of Piraeus, Athens \\ Polyxeni Moira, Technological Education Institute of Piraeus, Athens \\ Aikaterina Kikilia, Technological Education Institute of Piraeus, Athens
}

\begin{abstract}
Tourism is significantly affected by unpredictable and uncertain factors such as the occurrence of a terrorist attack, an epidemic outbreak or a natural disaster, etc. The impact of these phenomena on the tourist movement of the country or the place where the event occurred is aggravated by the way it is presented by the media both locally and internationally. The adverse climate gets worse by the issuance of travel advice that usually accompanies such phenomena and has the effect of limiting or even halting tourist flows. In order to identify and study the different types of travel advice that have been issued during international tourism crisis incidents, an internet search was carried out using keywords. Moreover, a study on the travel advice issued by major tourists' origin states, as the USA, Australia, Canada, Germany, the United Kingdom, etc. was carried out. Incidents (terrorist attacks, epidemics, natural disasters) which had a great impact on tourism were then selected. In addition, the issuance of travel advice, their different issuing authorities, the classification level and the impact on the tourism of the country or the place in question were examined. An analysis of the reaction and the instructions of major international organizations (World Health Organization, World Tourism Organization) concerning the management of such crises, directly or indirectly affecting tourism, were also analyzed. The study of the relevant websites, the international literature and the recorded incidents shows that the issuing of travel advice has negative effects on many sectors of tourism activity and is a bottleneck for tourism development. In fact, in many cases, travel advice is used by countries to exert pressure on other countries in order to achieve a desired result. Due to the enormous economic and social effects when issuing travel advice, the states proper management is necessary in order to minimize the negative consequences and avoid obstructing the free movement of tourists, as provided for in international treaties and declarations. As no systematic research on the impact of travel advice on a country and the degree of influence depending on the issuing entity (state, international organization or private entity) has been carried out so far, further investigation of the issue is suggested, by performing research, both on travelers and travel organizations on the effects of issuing travel advice.
\end{abstract}

Keywords: Tourism, Travel advice, Travel warning, Ethics, Code of ethics for tourism 


\section{SAVETI ZA PUTNIKE KAO FAKTOR INHIBICIJE KRETANJA TURISTA}

Sažetak

Nepredvidivi i nestabilni faktori, kao što su izbijanje terorističkog napada, izbijanje epidemije ili prirodne katastrofe, u značajnoj meri utiču na turizam. Uticaj ovih fenomena na turistička kretanja u zemlji ili oblasti gde se dati događaj odvio otežan je načinom na koji se isti medijski predstavlja u zemlji i inostranstvu. Negativna klima pogoršava se izdavanjem putnih preporuka koje obično prate takve fenomene i imaju efekat ograničenja ili čak zaustavljanja turističkih tokova. Kako bi se identifikovali i proučili različiti tipovi putnih preporuka izdatih tokom kriznih incidenata u međunarodnom turizmu, urađena je internet pretraga korišćenjem ključnih reči. Napravljena je i studija putnih preporuka izdatih od strane država porekla turista: SAD, Australija, Kanada, Nemačka, Ujedinjeno Kraljevstvo, itd. Izabrani su incidenti (teroristički napadi, epidemije, prirodne katastrofe) koji su imali veliki uticaj na turizam. Ispitano je i izdavanje putnih preporuka, razni organi koji su ih izdali, nivo klasifikacije i uticaj na turizam date zemlje ili mesta. Predmetom analize je bila i analiza reakcije i uputstava velikih međunarodnih organizacija (Svetska zdravstvena organizacija, Svetska turistička organizacija) u vezi sa upravljanjem takvim krizama koje direktno ili indirektno utiču na turizam. Proučavanje relevantnih sajtova, međunarodne literature i zabeleženih incidenata pokazuju da izdavanje putnih preporuka ima negativne efekte na mnoge sektore turističke aktivnosti i da predstavlja usko grlo razvoja turizma. Zapravo, u mnogim slučajevima, putne preporuke se koriste kako bi se izvršio pritisak na druge zemlje da bi se postigao željeni rezultat. Zbog ogromnih ekonomskih i socijalnih efekata pri izdavanju putnih preporuka, ispravno upravljanje istima od strane države je potrebno kako bi se minimizovale negativne posledice i izbeglo ometanje slobodnog kretanja turista, kao što je navedeno u međunarodnim sporazumima i deklaracijama. Kako do sada nije bilo sistematičnog istraživanja stepena uticaja i stepena uticajnosti putnih preporuka na neku zemlju prema entitetu koji je izdaje (država, međunarodna organizacija ili privatni entitet), savetuje se dalje ispitivanje ove oblasti putem istraživanja efekata izdavanja putnih preporuka, kako na putnicima, tako i na turističkim organizacijama.

Ključne reči: turizam, putna preporuka, putno upozorenje, etika, etički kodeks u turizmu

TIMS Acta (2016) 10, 13-26

\section{Introduction}

Nowadays, travelling constitutes an important activity of daily life. It offers satisfaction to tourists, as it gives them an opportunity to meet their needs for rest and recreation, to get to know other peoples and ways of life, escape from daily routine etc. (Mathieson \& Wall, 1982), while, at the same time, it facilitates international understanding between peoples (UNWTO, 2007). The positive effects of tourism are significant and have been the subject of various debates. Economically speaking, the tourism "industry" holds a leading position in many national economies, as it constitutes a major source of income and currency exchange, it creates jobs (Archer \& Cooper, 1998:73) giving the opportunity for prosperity and economic growth, particularly to countries which do not have alternative resources (Cleverton, 1979; Oppermann \& Chon, 1997).

However, since tourism is by nature a "fragile" social institution (Boniface \& Cooper, 2005; Lytras, 1998:78), it is significantly influenced by unpredictable and uncertain factors, such as the occurrence of terrorist attacks, an epidemic outbreak, a natural disaster etc. Moreover, the degree of impact of these phenomena on the tourist movement of the country where the event took place is aggravated by the way it is presented by the media, 
both locally and internationally. The negative climate is worsened by the travel advice accompanying such phenomena and causing the interruption of tourist flows in these regions (Moira \& Mylonopoulos, 2004:135).

\section{The research}

In order to identify and study the different types of travel advice which have been issued during international tourism crisis incidents, an internet search was carried out using keywords (Travel advice, travel warning, travel advisory, travel alert, etc). Moreover, a study on the travel advice issued by the major countries of tourists' origin, as the USA, Australia, Canada, Germany, the United Kingdom, etc. was performed. Incidents (terrorist attacks, epidemics, natural disasters), which had a great impact on tourism were then selected.

In addition, the issuance of travel advice, their different issuing authorities, the classification level and the impact on the tourism of the country or the place in question were examined. An analysis of the reaction and the instructions of major international organizations (World Health Organization, World Tourism Organization) concerning the management of such crises, directly or indirectly affecting tourism, were also analyzed.

The study of the relevant websites, the international literature and the recorded incidents shows that the issuing of travel advice has negative effects on many sectors of tourism activity and is a bottleneck for tourism development. In fact, in many cases, the travel advice is used by countries to exert pressure on other countries in order to achieve a desired result.

\section{Travel advice in tourism}

Travel advice is an instrument of information that goes beyond the level of mere information (travel information) of the place of destination regarding duty issues, requirements for visa granting, consular authority access, weather conditions, etc. The travel advice is interwoven with negative situations that pose serious dangers to the safety and health of travelers both at the destination and during the trip. Travel advice help citizens avoid dangers and difficulties. They provide up-to-date information on security conditions of the host country, including information on possible terrorist threats or problems relating to the law and order (Robertson et. al, 2006). According to Macmillan Dictionary the Travel Warning is an official notice in which a government warns its citizens not to travel to a particular country or region because it is dangerous ${ }^{1}$. According to the Business Dictionary the travel advisory is a formal warning issued by a governmental or international organization (such as the UN) advising caution in traveling to specified destinations due to reasons such as armed violence, civil or political unrest, high incidence of crime (specially kidnapping and/or murder), natural disaster, or outbreak of one or more contagious diseases ${ }^{2}$.

Travel advice is normally issued by the state and addressed to its citizens who intend to travel to a foreign country or are already there. Its adoption is considered to be the State's obligation (Dupont \& Steffen, 1997; Zuckerman, 2001; WHO 2003), through the competent ministry, which is usually the Ministry of Foreign Affairs, without excluding the intervention of the Ministry of Health or Tourism. The issuing of travel advice is not only a privilege of states. Travel advice is often issued by other organizations. Therefore, apart from the instructions of state of origin, there is travel advice of transnational origin i.e. that issued by the World Health Organization (WHO), the European Union ${ }^{3}$ and travel advice of private origin i.e. that issued by private agents of tourism, such as tour operators, travel agencies, etc ${ }^{4}$.

Travel advice of the state origin exerts great influence over citizens when making decisions about a trip, because they are generally characterized by the element of greater accuracy, objectivity and reflection regarding their issuing. Each country's Media, of course, tend to overemphasize the risks identified by the travel advice (APEC, 2004: 2-3, 18-19) and thereby magnify the obstacles which are already standing in the way of tourist development due to the adoption of travel advice (Mylonopoulos \& Moira, 2005:45-46). The same characteristics also apply to the travel advice issued by international organizations.

The content of a travel advice may refer either to safety or health issues.

A. The risks for traveler's safety have anthropogenic and natural origin. The anthropogenic hazards may 
derive from the social/political status (Norton, 1987:3033 ) or the social conditions of the country of origin (Ryan, 1993), the intermediate stations and the host country [increased criminality, robberies, assaults, murders, bombings, hostage taking, etc.]. They may be grouped a) according to the geographical criterion, i.e. relating to some larger geographical areas, exceeding the limits of a state [e.g. piracy in the maritime region of Southeast Asia), relating to the entire country (e.g. Afghanistan)], being restricted to a designated area within a nation [e.g. the region of Chiapas in Mexico (Moira, 2001:151)], or relating to some deprived urban neighborhoods [Rio de Janeiro, Moscow, New York, etc.], b) according to the social criterion, i.e. caused by antisocial behaviors and increased crime, particularly against tourists (thefts, robberies, murders, rapes, racism, etc.), c) according to the political criterion i.e. caused by terrorist threats or actions for political, religious, or other reasons [e.g. the Tamil rebels in Sri Lanka, in 1996, after an attack on a train which resulted in the death of 70 people and injury to 600 , stated that they consider tourism as an 'economic target', which resulted in the country being considered as an unsafe tourist destination (Moira, 2000:175) or the massacre at Luxor which caused the halting of the tourist flow to Egypt (Moira, 2001:39)], d) according to the geopolitical criterion i.e. arising from the general politico-economic situation of the country (political regime instability, civil war, intense reaction from minorities, a status which does not favor tourism, etc.) or the wider region (e.g. regions in Syria, regions in the Russian Federation, etc.).

The risks of natural origin derive from the natural environment of the place of destination. They may be categorized according to various criteria: a) according to the geological criterion i.e. they may result from earthquakes, (e.g. Japan, etc.), or volcanic activity (e.g. Indonesia, Iceland), b) according to the environmental criterion i.e. they derive from the natural environment and the peculiar weather conditions of the host country (e.g. hurricanes, floods, storms, drought, etc.)

B. The travelers health risks may originate from infectious diseases which can lead to epidemics or pandemics and are due to poor living conditions, noncompliance with the conditions of hygiene, lack of medical care, lack of organization for rapid response to medical emergencies e.g. malaria or typhoid fever in Africa or Asia, dysentery, yellow fever in Central Africa (Voropoulou-Simos, 2004), cholera in SE Asia, Ebola in Africa, etc.

\section{The distinction of travel advice}

The content of the travel advice reflects the level of risk faced by the traveler at the destination, as estimated by each country. Thus, travel advice are not presented in a uniform manner. The Australian Government/ Department of Foreign Affairs and Trade ${ }^{5}$, for example, notes that it does not maintain a strict classification system of travel advice, as it considers that this way people focus on code rather than reading the content, while in fact the content of the advice is what will actually enable the person to decide about the trip. In 2005 the Australian Government/Department of Foreign Affairs and Trade revised the system of travel advisories. The revision concerns the use of a more comprehensible language and the way advisories are presented. Security levels were restricted by being decreased from 7 to 5 . The levels ranged from normal safety precautions to the advice to not make the journey ${ }^{6}$.

In fact, the relevant website indicates that the levels of security risks are determined by comparison to the general security threats in a large Australian city in conjunction with the host country's capacity to deal with risks. Moreover, it highlights that travel advisories offer advice and they are tools designed to help travelers avoid difficulties during the trip ${ }^{7}$.

Later on, the categorization was limited even more. The levels were decreased to 4 . The first level concerns the "exercise of normal safety precautions" during the journey, whereas the fourth advises not to travel ("Do not Travel" $)^{8}$. Additionally, a colored bar is introduced to each travel advisory in order to make apparent the level of risk at a glance. Some advisories show more than one level. This may occur when the overall country is at a certain level, but different regions within the country are assessed to be at higher or lower levels due to particular risks or safety concerns ${ }^{9}$. Finally, clarifications on issues related to crime, credit and valuables transfer and instructions for parents traveling with their children are added. 
The Canadian Ministry of foreign Affairs initially kept a nine-level risk scale of travel advisories, whereas it issued advisories in the form of information and advice on safety issues, natural disasters, protests and health risks which could have had serious consequences during the journey. In 2005, through a newer revision, the wording of travel advisories was changed in response to the requests of the World Tourism Organization for homogenization of the terminology used to avoid confusion. Thus, travel advisories are of four risk levels starting from the "Exercise of normal security precautions", to the non-realization of the trip ("Avoid

Table 1. The travel advice system of the major tourism markets

\begin{tabular}{|c|c|c|c|c|c|}
\hline USA & Consular information & \multicolumn{3}{|c|}{ Public announcement } & Travel warning \\
\hline UK & $\begin{array}{l}\text { Unclassified travel } \\
\text { advice }\end{array}$ & \multicolumn{2}{|c|}{$\begin{array}{c}\text { Advice against travel unless on } \\
\text { essential business }\end{array}$} & \multicolumn{2}{|c|}{ Advice against travel in any case } \\
\hline GERMANY & $\begin{array}{l}\text { Unclassified travel } \\
\text { advice }\end{array}$ & \multicolumn{2}{|c|}{ Security Advice } & \multicolumn{2}{|c|}{ Travel Warning } \\
\hline \multirow[b]{2}{*}{ AUSTRIA } & \multirow[b]{2}{*}{$\begin{array}{l}\text { Good security } \\
\text { standard }\end{array}$} & & sk of security & & \multirow[b]{2}{*}{ Travel warning } \\
\hline & & $\begin{array}{l}\text { Alleviated risk of } \\
\text { security }\end{array}$ & $\begin{array}{l}\text { High risk of } \\
\text { security }\end{array}$ & $\begin{array}{l}\text { Very high risk of } \\
\text { security }\end{array}$ & \\
\hline FRANCE & \multicolumn{3}{|c|}{ Advice against travel unless on essential business } & Advice aga & el in any case \\
\hline
\end{tabular}

(Source: Glaesser, 2006. p.113)

all Travel" $)^{10}$. Thereby, the government of Canada transmits information to the public promptly, briefly and with clarity. The Canadian Ministry of Foreign Affairs particularly points out the fact that the decision to travel is the sole responsibility of the individual ${ }^{11}$.

Japanese government issues travel advice which is categorized in four levels ${ }^{12}$. Since Japanese travel around the world ${ }^{13}$, they are particularly interested in their own safety and are especially sensitive about security and health issues during the journey. It is typical that the issuing of level 2 travel advice prohibits travel agencies to plan any recreation trip to that particular destination. A level 4 travel advice urges immediate departure from the relevant country ${ }^{14}$.

Similar rating is maintained by other countries as shown in the following table:

Almost all countries which constitute a source of tourists issue travel advice for their citizens in the event of dangerous situations in the countries of destination. However, countries which constitute an important source of tourists, especially the USA, Canada, the United Kingdom, Germany, Australia, France, Japan, Italy, etc. issue systematically travel advice and operate relevant websites aiming to keep their citizens informed ${ }^{15}$.
In fact, the travel advice issued by countries that are major sources of tourists, such as the USA, Great Britain, Germany etc. constitute an important information system for tourism (Glaesser, 2003:129).

It should, however, be noted that the risk level of an area attracting tourists is not assessed similarly by the states. So after the terrorist attack on a popular tourist resort in Bali, Indonesia (Moira \& Mylonopoulos, 2004:127), on 12 October 2002, where 182 people were killed (56 Australians, 17 British, 12 Indonesians, 6 Germans, 6 Americans, 5 Swedish and 2 French tourists) and hundreds of others were injured, the Ministries of Foreign Affairs of the states whose citizens were victims, adopted different levels of travel advice, e.g. the U.S., France and the United Kingdom issued a travel advice of stern warning with which they discouraged their citizens from travelling to any destination in Indonesia, Germany issued a travel advice of simple advice which highlighted the danger of the destination (security advice), while Australia, despite having the majority of deaths, issued a travel advice not of a stern warning, but of public safety announcement (Glaesser, 2003:132) which pointed out the high risk level of the area. Nevertheless, the countries' reaction was different regarding the terrorist attack which took place in Bali three years later, resulting 
in 26 deaths and 125 injuries (Karantzavelou, 2005), including many tourists. The British Government decided not to issue a travel warning against Indonesia, but was limited to public awareness about the necessity or not to travel to the destination. It seems that the change of attitude of Great Britain arose after the bombing attacks in London, too. It should also be noted that Great Britain's Ministry of Foreign Affairs had been strongly criticized several times for the frequent issuing of travel advice in the past, even in cases where there hadn't been any particular danger. The Government of Australia just urged its citizens to avoid unnecessary travel to Indonesia and stressed that Australian citizens who are worried about their safety in Indonesia should seriously consider the possibility of returning to their homeland (Koumelis, 2005a). Similarly, after the terrorist attack on a tour bus in Egypt, in February 2014, Canada issued a travel advice which recommended avoiding all unnecessary travel to the country, and in particular it advised against all travel to the Sinai Peninsula (with the exception of the coastal resort of the Sharm El Sheikh, where it recommended to exercise caution ${ }^{16}$ ).

The United Kingdom recommended avoiding all travel to the Governorate of Sinai and any unnecessary trip to the other regions of the peninsula, including the Sharm El Sheikh. For the rest of the country it advised to be updated from the website about new advice ${ }^{17}$. The United States advised against all travel to the Sinai Peninsula ${ }^{18}$. Canada issued a general travel advice about reconsidering the need to travel to Egypt and against all travel to the Governorate of North Sinai and Suez ${ }^{19}$.

Similar variations are recorded in travel advice issued by the Member States of the European Union in the cases of Egypt, Syria and the Russian Federation. In the case of Egypt ${ }^{20}$, conflicting instructions were issued about avoiding all unnecessary travel ( 5 states), avoiding any unnecessary travel to certain areas (10 states), against all travel (one state, Spain), avoiding any travel to specific areas (10 states). One state, France, just recommended extreme caution while Greece did not issue any travel advice. In the case of the crysis in Syria ${ }^{21}$, 13 states recommended avoiding all travel, 12 advised their citizens to leave the country immediately, one (Italy) recommended caution and only 2 (Greece and Luxembourg) did not issue any travel advice.
In the case of the crisis in Russia, in view of the organization of the Winter Olympic Games, travel advice was divided even more. Ten states did not proceed to the issuing of travel advice, among which there were countries (Greece, Cyprus, Bulgaria) whose tourism markets depend on Russian tourists. Six countries recommended avoiding all unnecessary travel to certain areas, six avoiding travel to specific locations, three simply recommended caution and three pointed out that in some areas there was danger.

It is obvious that the issuing of travel advice is not only driven by the criterion of the risk of traveler's safety and health. It seems that the political factor plays an important role, i.e. the existing relations between states (Gaillard, 2003). Notably, as suggested by Canadian specialist epidemiologists, the only reason that Canada was included in the travel advice issued in 2003 for the onset of SARS was to placate China, which was first on the list, by including a western type country in the list (The Condro, 2003).

The issuing of advice may often intend to "punish a country" for its acts or omissions to the country issuing the advice. This was also pointed out by the SecretaryGeneral of the World Tourism Organization ${ }^{22}$ (UNWTO) when, in 2003, addressing the European Tourism Forum he stressed that many governments misuse travel advice 'punishing' unfairly multiple destinations (Frangialli, 2003:2). In addition the travel advice may constitute a way of exerting pressure to achieve a desired result $\mathrm{t}^{23}$. Respectively, the non-adoption of an advice, even if it is necessary, is also a political "weapon" in the case, for example, where its adoption would jeopardize the "good relations" with the country (Sharpley, G \& Sharpley, J., 1995, In Glaesser, 2006:116). These instructions are often not based on realistic and objective criteria, such as the travel advice issued by the U.S. for Cancun beach in Mexico claiming that "corrupt cops target tourists". The U.S. State Department in fact analyzed "the problem" claiming that "the deterioration of public disorder in Cancun, during the last weeks, is due to shortages of municipal funds for police officers' payments". It should be noted that the Mexican government accused the U.S. several times of "intervening in its own affairs" (Koumelis, 2005c). 
It may also be argued that the adoption of advice may be a political means of eliminating competition in favor of a rival country with a similar tourism product. Given that the role of the political factor in the issuing of travel advice has become apparent, several agents of the travel industry, public and private, encourage travelers to check the information on the hazards of a destination before they make a decision. In addition, many states have committed themselves to provide objective information on the dangerous tourist destinations, particularly UNWTO Member States, which have signed the Hague Declaration on Tourism, the Manila Declaration on World Tourism and the Global Code of Ethics for Tourism.

\section{The effects of travel advice}

All economic activities require a secure developmental environment. Which is more, the tourism sector is extremely vulnerable to any form of insecurity, which frightens travelers. The issuing of travel advice has adverse effects on many sectors of tourism activity and is becoming an inhibiting factor in tourism development. In fact, these effects are as big as the dependence of the state's economy on the tourism sector or on a particular tourist market ${ }^{24}$.

The issuing of travel advice in the case of SARS is a typical example. In 2003 the outbreak of SARS delivered a really heavy blow to tourism in the Asian continent. The World Travel and Tourism Council (WTTC, 2003) estimates that over three million people lost their jobs in the most affected areas (China, Hong Kong, Singapore and Vietnam). The total cost is estimated to have exceeded $\$ 20$ billion in GDP losses. According to the Wall Street Journal the losses in GNP were estimated at about \$2.2 billion for China, at \$1.1 billion for South Korea, \$1.7 billion for Hong Kong, $\$ 1.1$ billion for Japan, $\$ 930$ million for Singapore, $\$ 820$ million for Taiwan, $\$ 660$ million for Malaysia, \$490 million for Thailand, $\$ 400$ million for Indonesia, \$270 million for the Philippines, and \$111 million for Vietnam, amounts that eventually doubled (Saywell, Feoffrey, \& Shawn, 2003).

Tourist arrivals experienced a decrease of $70 \%$ or more in other Asian countries, even in countries which were not affected by the virus. Subsequently, WHO's information (2003) shows that SARS should not have had a greater impact on the global tourism than any other seasonal flu outbreak. ${ }^{25}$ However, the adoption of a General Travel Advice by the World Health Organization on 15 March 2003 triggered a chain reaction (Overby, Rayburn, \& Hammond, 2004:85).

A series of specific travel advice for Hong Kong, China, Taiwan and Toronto closed many borders. Communications from the WHO were unprecedented during its 45 years old history, as for the first time it issued a travel advisory for specific geographic areas because of an outbreak of an infectious disease (WTTC, 2003). In fact, it has been argued that measles is five times more infectious than SARS (Benitez, 2003, In McKercher \& Kaye, 2004).

Therefore, there is no doubt that travel advice has a hugely negative impact on tourism and travel flows in general, which in turn affect many other sectors of economic activity. This has been repeatedly pointed out, especially from the least developed countries, which often face health and safety problems, making them recipients of travel advice. Thus, during the 12th Conference of ICAO in Cairo, Egypt, the Eastern African states identified huge adverse impacts on their economy due to the adoption of continuous travel advice which led to a decline in arrivals by air to lower levels than those recorded after the terrorist attack on September $11^{26}$. Such a finding also emerges from the study submitted by the member states of APEC, strongly affected by barriers in the tourist movement due to the issuing of travel advice, particularly after the terrorist attack on September 11th (APEC, 2003:19). APEC Member States indicate that the upward trend of the travel advice issuing affects the choice of the destination together with the realization or not of the journey.

The effects of a travel advice are extended not only to the host country but also to the country of origin, because the production of tourism products circuit is affected at source. A typical example is the UK, whose government, after issuing travel advice for Saudi Arabia and Algeria, received complaints from tour operators, as they were unable to produce and promote travel packages for these countries. This weakness resulted in significant economic losses. The strong protests of tour operators together with the economic distress led to the revision of the travel advice, downgrading them to mere 
warnings in order to avoid unnecessary trips to those countries (Karantzavelou, 2004). The adverse economic impact was so fierce that Great Britain's Secretary of the Ministry of Foreign Affairs, Mr. Jack Straw, stated in his speech to Parliament on 22 June 2004: "in the future, only in case of terrorist threats involving large and persistent risk to humanity, should the Government intervene and issue advice against certain countries".

The issuing of travel advice actually removes the unimpeded tourist movement based on the Manila Declaration on World Tourism (OMT-WTO-BTO, 1980) and the Final Act of the 1975 Conference on Security and Co-operation in Europe ${ }^{27}$, the Tourism Bill of Rights (WTO, 1985), the Hague Declaration on Tourism (WTO, 1989) and the Code of Ethics for Tourism (WTO, 2001).

\section{The management of travel advice}

Given that the effects of a travel advice extend to all sectors of the global economy, the World Tourism Organization has repeatedly pointed out the problem of the issuing of travel advice. Since the issuing of travel advice directly affects the air transport of travelers, such discussions have taken place in the context of the ICAO conferences (2004).

According to the World Tourism Organization, in 2012 there were 1,035,000 tourist arrivals worldwide, 39 million more than the arrivals in 2011, recording an increase of 3.8\%. (UNWTO, 2013:3). Tourism revenues also recorded an all-time record, reaching 837 billion euros (1.075 trillion U.S. dollars) compared to 749 billion in 2011 (1.042 billion U.S. dollars) exceeding the \$1 trillion (UNWTO, 2013:8). In 2012, more than 3 billion passengers were transported by airlines (Air Transport Action Group, 2014). The largest volume of tourist movement worldwide in 2012, 52\%, was carried out by plane (UNWTO, 2013:5).

The issue of travel advice is also associated with the "Global Code of Ethics for Tourism" that emerged from the World Tourism Organization (WTO), was revised by the UN Committee for Social Development, and accepted by the Organization's General Assembly (UNWTO, 1999) in October 1999. The Global Code refers in particular to mutual understanding and mutual respect among people and societies, and provides instructions and guidelines for the achievement of tourism's benefits by the communities and host countries. It also gives instructions to tourism stakeholders on the implementation of their obligations regarding freedom of tourist travel.

In fact, the UNWTO's Secretary-General (Frangialli, 2004) points out that governments should cooperate with the global travel industry, in order for travel advice to be in line with the Global Code of Ethics (WTO, 1999).

More specifically, under the Article $6 \S 5$ of the Code, entitled "Obligations of stakeholders in tourism development": "Governments have the right - and the duty - especially in a crisis, to inform their nationals of the difficult circumstances, or even the dangers they may encounter during their travels abroad; it is their responsibility however to issue such information without prejudicing in an unjustified or exaggerated manner the tourism industry of the host countries and the interests of their own operators; the contents of travel advisories should therefore be discussed beforehand with the authorities of the host countries and the professionals concerned; recommendations formulated should be strictly proportionate to the gravity of the situations encountered and confined to the geographical areas where the insecurity has arisen; such advisories should be qualified or cancelled as soon as a return to normality permits" (UNWTO, 2001:7).

The Code sets relevant obligations to the mass media, and particularly the specialized travel press and the modern means of electronic communication. According to the Code, article 6, § 6, those means "should issue honest and balanced information on events and situations that could influence the flow of tourists; they should also provide accurate and reliable information to the consumers of tourism services" (UNWTO, 2001:7).

Over the last years an increase of travel advice adoption from various agencies, governmental and non-governmental, public and private, international institutions, organizations etc. is observed, mainly due to concern about the increase in natural and manmade disasters. The plethora of different classifications and degrees of intensity of travel advice lead to vague, complex and non-harmonized information (Gaillard, 2003) which often brings travelers into confusion, paralyzes the tourist industry and causes huge economic and social costs. In fact, according to the APEC, the 
problem is not so much in the issuing of travel advice, as their staying in force beyond the dangerous period (APEC, 2003:23), as well as the way they are handled by the media (APEC, 2004:18-19) which tend to glamorize destruction (Faulkner, 2001:141) and dramatize the chaotic situation caused by such crises.

Whereas the framework of issuing travel advice has undoubtedly improved, the states concerned are still skeptical about the necessity of their issuing. This distrust refers to the nature of the threat, the lack of geographical accuracy of the threat, the lack of consultation with the state facing the consequences of the advice ${ }^{28}$, the nonrevision or prompt revoking of the adopted advice and the discrepancy observed between travel advice issued by different countries for the same destination. Thus, in many cases it is imperative to manage travel advice in such a way as to maximize the safety of travelers, but also to minimize the negative impact on the travel and tourism development.

The management of the crisis caused by the adoption of travel advice in order to minimize its negative impacts is primarily the responsibility of the State - recipient and the authorities conducting tourism policy. Crisis management should be carried out through a carefully formulated "crisis management framework", which requires the involvement not only of public but also of private tourism stakeholders. A special crisis management unit, staffed with qualified personnel, technical equipment, having access to all levels of information, using the media and of course having the necessary infrastructure is essential (Glaesser, 2003:192, 224). The systematic cooperation and updating of the states involved in any way in the crisis is also significant in order to minimize the negative impacts of travel advice.

Experience shows that greater international cooperation and coordination among stakeholders is necessary in order to develop an effective response to international crises. At the same time an investigation of the base and the incentives of travel advice should take place (McKercher \& Kaye, 2004:718). In fact, the creation of a consultative mechanism to ensure the continuation of tourist activity after the dangerous period has also been proposed (APEC, 2003:23).

\section{Ethics for travel advice}

The World Tourism Organization, trying to define a framework of issuing Travel Advice, adopted at its General Assembly held at Dakar, Senegal in 2005, a recommendation concerning travel advisories (UNWTO, 2005).

According to the recommendation the GA, recognizing the importance of travel advice for countries of origin and host countries, adopted a framework of 'Ethics for travel advisories' based on guidelines for preparation, language version and their disclosure, as well as the cooperation with the relevant country. A wide variety of relevant governmental and nongovernmental sources should be used, whenever possible and appropriate, to collect information for preparing advisories. In addition, travel advisories should be accurate, relevant and appropriate, avoid ambiguous language, as well as bias and political considerations. They should be specific about the geographical location of the risk and the nature of the threat or risk and these should be defined through a robust and comprehensive process. An indicative reference to categories of threats and risks is thereby addressed, such as political (due to political process), social (crime, delinquency), related to terrorism, environmental (natural disasters), industrial (such as chemical or nuclear) hazards related to health (communicable disease status and emergencies, such as epidemics) and related to transportation systems.

Information contained in travel advisories should be published on a central, easy-to-use and widely known website in order for the various agencies involved to be able to coordinate the message. Travel advisories should be regularly updated, preferably within a period of three months. Prior to departure, travelers should be encouraged to consult all sources of information, both governmental and non-governmental.

Finally, the World Travel Organization's recommendation highlights that affected countries should provide timely and accurate advice to the issuing countries about changes of circumstances through the established communication channels. It is pointed out, however, that it is up to the country issuing the travel advice to make its own assessment for the safety and security of its citizens. 


\section{Conclusion - Proposal}

Tourism is a productive sector of economy and constitutes the only source of wealth and development for many countries. Since unimpeded tourist movement is actually undermined by the issuing of travel advice, the international community shouldn't create obstacles to tourism development. The fair use of travel advice is therefore essential to ensure respect to the communities and destinations (Frangialli, 2003:2).

The adoption of travel advice has negative impacts on several tourism sectors and is becoming an inhibiting factor to tourism development. In many cases, the travel advice is used by states as a means of exerting pressure on other states in order to achieve a desired result. Therefore, due to frequent abuse of travel advice, the WTO is making substantial efforts for countries to use the travel advice in a reasonable way, so that it remains a means of information and precaution and not a means of pressure. Through the World Tourism Organization declarations, governments are urged to refrain from introducing restrictions, formalities or other barriers to travelers' entry or exit, as well as import barriers, physical or psychological, to the tourists flow from one country to another (Mylonopoulos, 2003:110) and finally states are invited to "refrain from the war of travel advice (FAL, 2004)".

Hence, a lack of unity concerning the rating of travel advice by the major countries of travelers' origin is apparent. Based on the criterion of hazard, travel advice could be divided into simple advice, public safety announcements and stern warnings. This coding would help to address uniformly hazardous situations and their impact on tourism industry. Travel advice having the form of simple advice are addressed to travelers in order to point out the dangers of the destination and enable them to decide in a realistic manner whether to make the trip or not. Travel advice with a public safety announcement nature are addressed to travelers so as to take increased measures to protect themselves in case of traveling to a dangerous destination, especially for certain areas of that destination or for certain activities. Travel advice in the form of a stern warning are addressed to travelers in order to prevent them from making the journey to dangerous destinations or to encourage them to depart from dangerous areas by any possible means.

As no systematic research on the impact of travel advice to a country and the degree of influence depending on the issuing entity (state, international organization or private entity) has been carried out so far, further research of the issue is suggested, by performing research, both on travelers and travel organizations on the effects of issuing of travel advice.

\section{FOOTNOTES}

1 Macmillan Dictionary, In http://www.macmillandictionary.com/ dictionary/british/travel-warning, access 20/02/2014

2 Business Dictionary, In http://www.businessdictionary.com/ definition/travel-advisory.html, access 20/02/2014

3 The European Commission operates a website titled Consular Protection, which provides information on the European Union's Member States travel advice for a third country (http://ec.europa. eu/consularprotection/showMap?tab=4).

$4 \quad$ e.g. the travel agency Lonely Planet, publishes hardcopy travel guides and has an extremely updated internet website www. lonelyplanet.com

5 Australian Government/Department of Foreign Affairs and Trade, In http://www.smartraveller.gov.au/zw-cgi/view/Advice/, access $24 / 2 / 2014$

6 A typical example is the travel advice issued for Lebanon on 18-7-2006 stating that "We strongly advise you to reconsider your need to travel to Lebanon at this time because of the unpredictable security situation", The Australian Foreign Ministry (2006). «Departure from Lebanon», Travel Bulletin, http://www. smartraveller.gov.au/advice meaning.html, access 18/7/2006

7 Australian Government/Department of Foreign Affairs and Trade, In http://www.smartraveller.gov.au/advice_meaning.html, access $18 / 7 / 2013$

8 Australian Government / Department of Foreign Affairs and Trade, In http://smartraveller.gov.au/travel-advice-explained. html tᄁv 24/02/2014

9 For example, the advice issued on 22 February 2014 for Egypt is level 3 i.e. it advises travelers to reconsider their need to travel while, especially for the region of North Sinai, the travel advisory is level 4, i.e. it refers to avoiding to travel, (Australian Government / Department of Foreign Affairs and Trade (2014)

10 Government of Canada (2014). In http://travel.gc.ca/travelling/ advisories/faq\#whatdo, access 24/02/2014

11 Government of Canada (2014). In http://travel.gc.ca/travelling/ advisories/faq\#when, access 24/02/2014

12 Ministry of Foreign Affairs of Japan, Press Conference 23 April

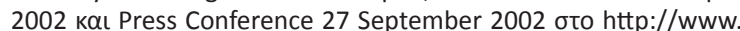


mofa.go.jp/announce/press, the travel advice of Japan after the reform in April 2002 were changed from five to four levels and concern, individual travelers instead of tourist packages. The issuing language is Japanese, at http://www.mofa.go.jp/ announce/announce/2002/4/0425.html, access 24/02/2014

13 The number of Japanese who traveled abroad increased to 17.472.615 Japan Tourism marketing Co, Historical Statistics - Japanese Tourists Travelling Abroad, Historical figures of the number of monthly Japanese departure by destination, In http:// www.tourism.jp/en/statistics/outbound/, access 24/02/2014

14 Ministry of Foreign Affairs of Japan (2014). In http://www. mofa.go.jp/announce/announce/2002/4/0425.html, access $24 / 02 / 2014$

15 e.g. for Italy, at www.viaggiaresicuri.mae.aci.it and http://www. viaggiaresicuri.it/index.php?id=3054\&mese=Febbraio_2014

for Japan, at http://www.mofa.go.jp/announce/ announce/2002/4/0425.html

for USA, USA, Department of State, In http://www.travel.state. gov/content/travel/english.html, \& http://travel.state.gov/ content/passports/english/alertswarnings.html

for Austria, http://www.bmaa.gv.at/view.php3?r $\mathrm{id}=1 \& L N G=e n \&$ version

for the UK, https://www.gov.uk/how-the-foreigncommonwealth-office-puts-together-travel-advice

for Australia, http://www.smartraveller.gov.au/zw-cgi/view/ Advice/

for Canada, Government of Canada, http://travel.gc.ca/ travelling/advisories

16 Government of Canada (2014), In http://travel.gc.ca/ destinations/egypt, access 20/02/2014

17 Government UK (2014), In https://www.gov.uk/foreign-traveladvice/egypt, access 20/02/2014.

18 U.S. Department of State, In http://travel.state.gov/content/ passports/english/alertswarnings/egypt-travel-alert.html, access $19 / 2 / 2014$

19 Australian Government (2014), Egypt, http://smartraveller.gov. au/zw-cgi/view/Advice/Egypt

20 On 16 February 20144 tourists were killed after a terrorist attack on a bus in the region of Taba at the northern Sinai. The bus was carrying Korean tourists to the monastery of St. Catherine in Sinai. (Hamza \& Choi, 2014). The group that claimed responsibility for the attack stated that tourists constitute a target and warned them to leave the country immediately (Vick, 2014).

21 Crisis in Syria started on 15 March 2011, with demonstrations against the government's economic and policy changes. The events resulted in an armed rebellion which turned into a civil war. According to the United Nations by September 2013 deaths had exceeded 120,000 people (Alliance News, 2013)

22 Since 2003 it was transformed into a specialized organization of UNO and its name was changed from WTO to UNWTO
23 Large travel agencies warned that tourists sightseers would be prevented from visiting the region of Chania if the biological purification of the northern axis of Chania is not completed within 2006. Such advice abroad is translated as avoiding the visit to Crete in general. (Koumelis, 2005b)

24 Gambia constitutes a typical example. The dependence of the tourism sector mainly on the British market, the military crisis of 1995 and the travel advice of Britain, led to the departure of British tourists from the country. The decline of tourism movement from Britain by $73 \%$ resulted in a shock of the entire economy of the country with losses of at least 1000 jobs only in the tourism sector and closing down of at least eight hotel units. (Sharpley G. and J. Sharpley, 1995, In Glaesser, 2003:158-159).

25 The account of the outbreak showed that 8,100 people in total became ill around the world. $97.7 \%$ of the cases occurred in China, Hong Kong, Taiwan, Singapore and Canada, less than 750 died, while $98.3 \%$ of the losses concerned the above areas.

26 Tourist arrivals in Kenya in 2003 decreased by 30,770 persons compared to 2002. (ICAO, 2004)

27 Conference on Security and Co-operation in Europe (1975). art. 6. Co-operation in other areas, Promotion of Tourism. Final Act, Helsinki, 1 August. 6. Co-operation in other areas, Promotion of Tourism

28 The need for communication and information of the country issuing the travel advice with the country against which it is issued has repeatedly been pointed out by states recipients of travel advice as illustrated by the report of the State of South Africa, at a meeting of the UN Counter Terrorism Committee. (UN, 2004:8).

\section{REFERENCES}

Air Transport Action Group. (2014). Facts and Figures. Retrieved from http://www.atag.org/facts-and-figures.html 2014 Feb 25.

APEC. (2003). APEC Tourism Impediments. Sydney, Australia: Dain Simpson Associates. February, Study Stage 1. TWG 04/2001.

APEC Tourism Working Group, APEC. (2004). APEC Tourism Impediments Study. In: Conference Board of Canada, Ottawa, Canada. Stage 2. Final Report.

Archer, B.H., \& Cooper, C. (1998). The positive and negative impacts of tourism. In W. Theobald (Ed.), Global Tourism: The Next Decade, 2nd ed. Oxford: Butterworth-Heinemann.

Australian Government, Department of Foreign Affairs and Trade. (2014). Egypt. Retrieved from http://smartraveller.gov.au/zw-cgi/ view/Advice/Egypt 2014 Feb 24.

Australian Government, Department of Foreign Affairs and Trade. Retrieved from http://smartraveller.gov.au/travel-adviceexplained.html 2014 Feb 24.

Benitez, M. (2003). Virus unchecked would have affected billions: Professor. South China Morning Post, September 27:C3. 
Boniface, B., \& Cooper, C. (2005). The future geography of trave and tourism. In B. Boniface \& C. Cooper (Eds.), Worldwide destinations; The geography of travel and tourism, 4th. Italy: Elsevier Butterworth-Heinemann.

Business Dictionary Retrieved from http://www.businessdictionary. com/definition/travel-advisory.htm 2014 Feb 20.

Cleverton, R. (1979). The Economic and Social Impact of International Tourism on Developing Countries. London: Special report, Economist Intelligence Unit.

Co-operation in other areas, Promotion of Tourism. (1975). Conference on Security and Co-operation in Europe, 1975-08-01, Helsinki. Final Act, art. 6.

Dupont, H. L., Steffen, R., \& eds, (1997). Textbook of Travel Medicine and Health. London: BC Decker.

European Commission. Consular Protection for EU citizens. Retrieved from http://ec.europa.eu/consularprotection/showMap?tab=4 2014 Feb 20.

Facilitation (FAL) Division. (2004). Developments since the Eleventh Session of the Division. Cairo, Egypt. (Presented by the East African Community States; Kenya, Tanzania, Uganda), Twelfth Session, Agenda Item 1: FAL/12-WP/82/20-3-04,, 22 March to 2 April.

Faulkner, B. (2001). Towards a framework for tourism disaster management. Tourist Management, 22.

France urges action on Syria, says 120,000 dead (2013) 25 September 2013. Retrieved from http://www.Ise.co.uk/AllNews. asp?code=loegkpgo\&headline=France_urges_action_on_Syria_ says_120000_dead 2014 Feb 2.

Frangialli, F. (2003). A Great Turning Point. Address to the European Tourism Forum by Secretary-General of the World Tourism Organization. Venice, Italy. 29 November.

Frangialli, F. (2004). Travel advisories and trade liberalization high on UNWTO Quality Support Committee agenda. Madrid: UNWTO Secretary-General, UNWTO Press and Communications Department. 16 April.

Gaillard, W. (2003). A Review of the Air Transport Industry. Retrieved fromhttp://www.iata.org/pressroom/speeches/ 2003/2003-0804-01.htm

Glaesser, D. (2006). Crisis Management in the Tourism Industry. Oxford: Butterworth-Heinemann.

Goverment UK. (2014). How the Foreign \& Commonwealth Office puts together travel advice. Retrieved from https://www.gov.uk/howthe-foreign-commonwealth-office-puts-together-travel-advice 2014 Feb 18.

Goverment UK. Retrieved from https://www.gov.uk/foreign-traveladvice/egypt 2014 Feb 20.
Government of Canada. (2014). Retrieved from http://travel.gc.ca/ travelling/advisories/faq\#whatdo, access 24/02/2014 and http:// travel.gc.ca/travelling/advisories/faq\#when 2014 Feb 24.

Government of Canada. Retrieved from http://travel.gc.ca/travelling/ advisories

Goodall, B. (1987). Tourism policy and jobs in the United Kingdom. Built Environment, 13(2), 109-123.

Hamza, H., \& Choi, J. (2014). Egypt: Suicide bomber behind tourist bus attack. AP, 17/2/2014. Retrieved from http://bigstory.ap.org/ article/egypt-suicide-bomber-caused-deadly-bus-blast 2014 Feb 25.

HCDCP /Ministry of Health. Retrieved from http://www.keelpno.gr/elgr/ 2014 Feb 20.

ICAO/ Facilitation (FAL) Division. (2004). Travel Advisories. Cairo, Egypt. (presented by the East African Community States; Kenya, Tanzania, Uganda). Agenda Item 1: Developments since the Eleventh Session of the Division. FAL/12-WP/82/20-3-04, 22 March to 2 April.

ICAO/ Facilitation (FAL) Division. (2004). Report of Division to the Plenary on Agenda it. 1. Cairo, Egypt. Twelfth Session, FAL/12WP/113/31-3-04, 22 March to 2 April.

ICAO/ Facilitation (FAL) Division. (2004). Synergy in Tourism and Aviation Facilitation. Cairo, Egypt. Twelfth Session, FAL/12-WP/25, 30/1/04, 22 March to 2 April, par. 2.3.2.

International Civil Aviation Organization. (2004). S.A.F.E. - The WTO Strategy on Security And Facilitation Enhancement, Assembly. Executive Committee and Economic Commission. 35th Session, A35-WP/107, EX/39, EC/18, 24-08-04.

Japan Tourism Marketing Co. Historical Statistics: Japanese Tourists Travelling Abroad, Historical figures of the number of monthly Japanese departure by destination. Retrieved from http://www. tourism.jp/en/statistics/outbound/ 2014 Feb 24.

Karantzavelou, V. (2005). New terrorist attack strikes Bali and endangers tourism. Monday, 3 October. Retrieved from www. traveldailynews.gr

Karantzavelou, V. (2004). The ministry of Foreign Affairs of Great Britain changes the travel advice for Saudi Arabia and Algeria. Thursday, 22 July. Retrieved from www.traveldailynews.gr

Kondro, W. (2003). Canadians still stung by WHO's SARS travel advisory, Medicine and Health Policy, The Lancet, Vol. 361, Iss. 9369, May 10, p. 1525.

Koumelis, T. (2005). Diverse positions of states in issuing travel advice for Bali. Friday. Retrieved from www.traveldailynews.gr

Koumelis, T. (2005). Crete faces the risk of a travel advice adoption. Friday. Retrieved from www.traveldailynews.gr

Koumelis, T. (2005c). USA's travel advice for Cancun's beach. Friday. Retrieved from www.traveldailynews.gr 
Lytras, P. (1998). Tourism Sociology. Athens: Interbooks.

Lonely Planet. Retrieved from www.lonelyplanet.com

Macmillan Dictionary. Retrieved from http://www.macmillandictionary. com/dictionary/british/travel-warning 2014 Feb 20.

Mathieson, A., \& Wall, G. (1982). Tourism Economic, Physical and Social Impacts. London: Longman.

McKercher, B., \& Kaye, C. (2004). The Over-Reaction to SARS and the Collapse of Asian Tourism. Annals of Tourism Research, Research Notes and Reports, 31(3)

Ministry of Foreign Affairs of Japan. (2002). Press Conference 23 April 2002 ка Press Conference 27 September 2002. Retrieved from http://www.mofa.go.jp/announce/press, and http://www.mofa. go.jp/announce/announce/2002/4/0425.html 2014 Feb 24.

Ministero degli Affari Esteri. Retrieved from www.viaggiaresicuri.mae. aci.it \& http://www.viaggiaresicuri.it/index.php?id=3054\&mese= Febbraio_2014 2014 Feb 2.

Ministry of Foreign Affairs of Japan. Retrieved from http://www.mofa. go.jp/announce/announce/2002/4/0425.html 2014 Feb 20.

Moira, P., \& Mylonopoulos, D. (2004). The parameter of terrorism in the international environment of tourism. Scientific Journal of Applied Research, 9(1)

Moira, P., \& Mylonopoulos, D. (2005). The tourism consumption of film and television image. Review of Economic Sciences, 7, TEI of Epirus.

Moira, P. (2000). Tourism Geography. Asia. Athens: Stampoulis.

Moira, P. (2001). Tourism Geography. Africa-America- Oceania. Athens: Stampoulis.

Moira, P. (1999). Tourism Geography. Europe. Athens: Stampoulis.

Mylonopoulos, D. (2003). The terrorist threat in air transport as an inhibiting factor of tourism development. Tourism Scientific Review, 1

Norton, G. (1987). Tourism and International Terrorism. The World Today, 43(2)

OMT-WTO-BTO, (1980). Manila Declaration on World Tourism. Art. 3.

Oppermann, M., \& Chon, K.S. (1997). Tourism in Developing Countries. London: Thompson.

Overby, J., Rayburn, M., Hammond, K., \& Wyld, D.C. (2004). The China Syndrome: The Impact of the SARS Epidemic In Southeast Asia. Asia Pacific Journal of Marketing and Logistics, 16(1), 69-94.

Pizam, A., \& Milman, A. (1993). Social Impacts of Tourism: Host perceptions. Annals of Tourism Research, 20(3), 660-665.

Robertson, D., Kean, I., Moore, S., Gurtner, Y. K., Holcombe, C., \& Wilks, J. (2006). Tourism Risk Management. An Authoritative Guide to Managing Crises in Tourism. Singapore: Asia-Pacific Economic Cooperation (APEC)
Ryan, C. (1993). Crime, Violence, Terrorism and Tourism. Tourism Management, 14(3), 173-183.

Saywell, (., Geoffrey, A. F., \& Shawn, W. C. (2003). «SARS deals blow to Asian economies», Analysis shows virus could drain $\$ 10.6$ billion from 2003's forecast GDP. Wall Street Journal, April 21: A10.

Sharpley, G., \& Sharpley, J. (1995). Travel advice-security or politics. In: Security and risks in Travel and TourismProceedings of the International Conference, Mid Sweden University. ButterworthHeinemann. 168-182. in Glaesser, Crisis Management in the Tourism Industry.

Medicine and Health Policy. (2003). The Lancet Publishing Group. May 10.

The Australian Foreign Ministry. (2006). Departure from Lebanon Travel Bulletin, Retrieved from http://www.smartraveller.gov.au/ advice_meaning.html $2006 \mathrm{Jul} 18$.

The Australian Foreign Ministry. Retrieved from http://www.bmaa. gv.at/view.php3?r_id=1\&LNG=en\&version 2014 Feb 19.

UN. (2004). Threats to international peace and security caused by terrorist acts. New York. S/PV.4921 (Resumption 1), 921st meeting, Thursday, 4 March.

UNWTO. (2001). Global Code of Ethics for Tourism: Approval of the protocol of implementation. Seoul, Republic of Korea.Osaka, Japan. Resolution adopted by the UNWTO General Assembly A/ RES/438(XIV) Corr.2, Fourteenth session, September.

UNWTO. (2004). International Tourist Arrivals by Generating Region and Destination Region 2003. December.

UNWTO. (2006). World Tourism Barometer. June.

UNWTO. (2005). General Assembly, Recommendations on Travel Advisories. A/16/RES, agenda item 22, documents $A / 16 / 22$ and A/16/22 Add.1, 28/11-2/12/.

UNWTO. (2007). Tourism For International Understanding. 31 October. Retrieved from http://www.odysseymediagroup.com/apn/ Editorial-Associations.asp?Report|D=270507 2014 Feb 26.

UNWTO. (2013). Tourism Highlights. Edition, access 25-2-2014. Retrieved from http://mkt.unwto.org/publication/unwtotourism-highlights-2013-edition

U.S. Department of State. Retrieved from http://travel.state.gov/ content/passports/english/alertswarnings/egypt-travel-alert. html 2014 Feb 19.

USA, Department of State. Retrieved from http://www.travel.state. gov/content/travel/english.html, \& http://travel.state.gov/ content/passports/english/alertswarnings.html 2014 Feb 20.

Vick, K. (2014). Egypt Terror Group Gives Tourists Two Days to Get Out. Time World, 17/2/2014. Retrieved from http://world.time. com/2014/02/18/egypt-sinai-ansar-jerusalem/

Vorropoulou, N., \& Simou, E. (2004). Travel Medicine. Propombos. 
WHO. (2003). International Travel and Health. Geneva.

WHO. (2003). Summary of Probable SARS Cases with Onset of IIIness from 1 November 2002 to 31 July 2003. Retrieved from http:// www.who.int/csr/sars/country/table2003_09_23/en/ 2003 Sep 23.

WTO. (1985). Tourism Bill of Rights and Tourism Code.

WTO. (1989). The Hague Declaration on Tourism.

WTO. (1999). Approval of the Global Code of Ethics for Tourism. Santiago, Chile. Resolution adopted by the UNWTO General Assembly A/ RES/406(XIII), Thirteenth session, September - October.

WTO. (2001). Global Code of Ethics for Tourism. In Global Code of Ethics for Tourism. Resolution adopted by the General Assembly, 21 December, A/RES/56/212.

WTTC. (2003). Special SARS Analysis: Impact of Travel and Tourism (Hong Kong, China, Singapore and Vietnam reports). London: World Travel and Tourism Council.

Zuckerman, J.N., \& ed., (2001). Principles and practice of travel medicine. Chichester: J. Willey \& Sons.

Datum prijave rada: 30.12 .2015 .

Datum prihvatanja rada: 12.01.2016.

\section{Kontakt}

Dimitrios Mylonopoulos, Piraeus University of Applied Sciences, Technological Education Institute of Piraeus,

P. Ralli and Thivon 250, Athens, Greece

E-mail: dimilon2002@yahoo.gr

Polyxeni Moira, Piraeus University of Applied Sciences, Technological Education Institute of Piraeus,

P. Ralli and Thivon 250, Athens, Greece

E-mail: xeniamoira@yahoo.gr

Aikaterina Kikilia, Piraeus University of Applied Sciences, Technological Education Institute of Piraeus,

P. Ralli and Thivon 250, Athens, Greece

E-mail: katkik4@yahoo.com 